\title{
The intertext of modernism in Crônica da casa assassinada, de Lucio Cardoso
}

\author{
William Valentine Redmond*
}

\begin{abstract}
This article reflects on the many opinions about the author of Crônica da casa assassinada as a modernist or postmodernist writer. Examining the narrative techniques used by the author, maybe influenced by his wide reading of foreign literatures, it may be possible to clarify a little the question of the position of Lúcio Cardoso in relation to the literary movements of the twentieth century. His personal experience as a writer passes through the process of impersonalisation, transforming his masterpiece into a universal symbol. It is hoped that this paper will show how this transformation of his personal experience comes across to the readers in the form of a modernist and not, as some say, a post modernist novel.
\end{abstract}

Keywords: Lúcio Cardoso. Modernism. Postmodernism.

There have been some attempts to place Cardoso among the postmodernists. Since the novel was published in 1959, it would be well after the beginning of what is called by many the postmodernist period of Brazilian literature. There was a thesis defended in the University of Campinas where the title includes the phrase "Lúcio Cardoso, the postmodernist". But in this chapter, an attempt will be made to defend the thesis that Lúcio Cardoso has in his final novel, the very essence of modernism to a very high degree and it would be erroneous to try and place him among the post modernists.

I would like to state clearly from the start the vision and the understanding of Postmodernism that seems to sum up and collect all the ideas on the subject and give a simple but all embracing sense to the complexity of writing on the subject. Around the period of student unrest of 1968 in Europe, literature moved into a Postmodernist mood. Postmodemist literature, it would seem, relates to Modernist literature in the sense of continuing the same general goal of challenging and disturbing established habits of thought. But it is post or beyond Modernism in the sense that the challenge has now become much more radical. Whereas Modernist writers aimed to reinvigorate perception, which had been deadened by habit, and language which had been staled by clichés, Postmodernist writers now questioned

* Centro de Ensino Superior de Juiz de Fora - CES/JF. 
the very nature of perception and the very nature of language. No longer is it sufficient to clear out the mediating passages so that the subject may gain better knowledge of the object. For Postmodemists, both subject and object are caught up within the passages, and knowledge in the traditional sense is out of the question and impossible.

This is in radical opposition to the view of the nineteenth Century which had been characterised by a unified view of the world. There was no longer, it is true, the Christian view of reality, but the Christian morals and Christian structure for society which had been taken over by Illuminism guaranteed a shared view of life, of society and of family life, of what a person should do and what lay in store for humanity with respect for the basic principles of respect for reason, application of their ideas to family and social life and the progressive march forward of mankind. Behind it all was the certainty that man could know, and that the writer could put this knowledge onto the page and transmit to the reader, a rarefied and carefully worked out vision of reality, crystallised in beautiful language and produced by a privileged intelligence.

This unified view of the world found its triumphant expression in the literary form that best adapted to crystallising this worldview, the novel. Just as the epic had been ideal for the aristocracy to express their view of life, their values and their dreams and hopes, so too this literary genre served ideally the new emerging middle class with their conservative morals and their hope in Illuminism. The novel became the burgher epic, identified with the limited reading public of the day, which was the urban middle class. It manifested their social, moral and secular view of the world based on the certainty of sequential moral growth and the belief in a progressive view of the self and society. What was valued in this type of literature was the force of the analysis, the application of great ideas to living but with the shared view of society: this analysis was always for our modern society rather oversimplified and offers but a monologic view of the complexity of this reality.

But with the end of the century, several factors among many others contributed to the shaking of the certainties of this worldview. The continual attack on religion by the scientific movements of the late 19th century especially propelled by the new ideas of the theory of evolution and the proof of apparent gross errors in the bible threw doubts on the certainties of the religious past. Then the philosophy of the time with its emphasis on the impossibility of the real knowing of things below the surface as expressed in Phenomenology showed that man had but a superficial knowledge of himself, other human beings and the reality around him. Then the 
discovery of the unconscious mind with the discoveries of Freud shattered the certainty of accepted standards of goodness and sanctity and questioned it with unconscious motivations. Nietzsche too brought uncertainty into the understanding of society. He saw that the world was pushed forward not by the noble principles of Illuminism and implicit Christianity but by the blind force of will and desire. He puts forcefully that truth is not something which is present and which had to be found and discovered. It is something which has to be created and which gives its name to the will to overpower, which in itself has no purpose: to introduce truth is an active determining, it is not a process of becoming conscious of something, which in itself is fixed and determined.

Besides, Saussure was discovering that man did not dominate language but was dominated by language. Langue was that system of rules and categories which make utterances possible and since language is what makes human beings human, the system of langue must be implanted at a very early stage, before the individual is able to exercise any power of choice or control. Saussure (1974) states clearly that a language cannot therefore be treated simply as a form of contract. The linguistic sign eludes the control of the will. All these discoveries of the controlling of humanity beyond the conscious certainty of the human mind destroyed the old certainties and left man with a deep epistemological doubt on his ability to know reality.

Added to this, there were the political and international realities that shattered the old status quo. Not only the Russian Revolution, but principally the First World War brought into question the whole belief in the progressive view of self and the society. Man saw that man produced evil as the bee produces honey, as William Golding put it.

The Modernist movement began at this moment in history of deep doubt and anguished self questioning because of these new philosophies, the profound religious doubt and the new terrible and harrowing experience of world war, which resulted in the fragmentation and lose of any unified world view.

Modernism was, therefore, a literary response to the break-up of the worldview of the writers at the turn of the century. There was no longer a shared world view and therefore the genre that expressed this worldview was placed in checkmate. It continued on shifting ground. Instead of the whole direct narrative of the reliable narrator stating cleaning ethical rules and dictating indirectly moral principles and rewarding and punishing characters in the story in accordance with their obedience to the basic principles of the world view of the bourgeoisie class, we have a new approach to things. 
It was necessary not to show the certainty of a view of life, but the ambiguity and the complexity of the anguished human being unable to see the way forward, unable to understand the chaos of the fragmented experience that was being lived through. One of the techniques was the new form of narrative which freed the text from the domination of the principles of logic and of chronology. It retreated inside the consciousness of the characters and the technique denominated stream of consciousness narrates from the mind and offers us chunks of unordered experience, without internal meaning or sense and the order is sought for in some outside structure far beyond the traditional organising feature of time and causality and the certainty of the progressive view of self. Joyce gives us order by the mere linking with the epic structure of twelve books of Homer but in the end, it offers no interpretation of life but just the rough elements of human experience, portrayed in all its disordered complexity. Virginia Wolf shows the chaos illuminated in moments of epiphany when the meaningless of life is removed for a moment just as if the circulating light of the lighthouse shows the boat for a tiny moment in the darkness and fog of the sea. But it just illuminates a little space for the looker on but gives no meaning to the whole complexity of the movement of life and existence.

Another way of showing the uncertainty and reveal the unreliability of the narrator to know the facts was by offering a multiple look of the basic facts of the story showing things from various points of view. Crônica da casa assassinada is a fine example of this complexity and ambiguity of point of view and of moral vision. The novel offers us a complex and strange narration of the happenings of the farmhouse of the Meneses in a small city in the interior of Minas Gerais, the state where the author had been born and brought up.

The novel is organised with a flexible structure, distributed among "reflectors of consciousness" to use the phrase of Henry James in his preface to The wings of the dove. A number of different narrators mediate the elaboration of the story and we receive the facts and the climate of each period from different points of view as the characters alternate their accounts of the happenings that take place in the farmhouse of the Meneses. The author avoids the use of the name chapter and offers us fifty-six numbered segments but giving us the identification and the peculiarities of each composition. There are letters, diaries to which we also have added statements, witness reports and memoirs. But behind this complexity of registers, some written some oral, there is an organisation element which makes them coherent and connected and there seems to be a compiler behind it all. This figure calls in the different segments as there is a slow and complex progression to 
the elucidation of a possible crime committed long ago in the past and when most of the main characters are long gone to their uneasy rest.

The order of the segments tries to piece together the narratives, and one sees that the compiler giving us an idea of where each part comes from. The segment starts with a rubric which tells us what type of text we have. There is a confession of Ana, there is the narration of Father Justino, there is a letter of Nina to the Colonel, and there is the diary of André and so on. Each narrator has a different level of knowledge of the facts, a different ability in self expression, a greater or less ability of intellectual perception and sagacity. The reports of the local chemist and the local doctor are called in to give important facts that explain the nature of the happenings and it is the finally post scriptum of the priest, who in the Catholic community in the interior of Minas Gerais, has, via confession, the final word in ending the mismeetings and suffering of the narrative.

The doctor in his third narrative gives us information on the central questions of the novel despite his advancing age. In the 24 segment, he tells us:

E finalmente concordo em narrar o que presenciei naquela época, apesar de serem fatos tão antigos que provavelmente já não existe mais nenhum dos personagens que neles tomaram parte. Bem pensado, é talvez este o motivo que me leva a usar a pena, e se a letra parece aqui ou ali um pouco mais tremida, é que a idade não me permite escrever com a facilidade de outros tempos, nem a memória é tal a ponto a acudir ao meu chamado. No entanto, creio poder precisar exatamente o dia a que o senhor se refere. (CARDOSO, 1959, p. 243).

Father Justino, as his name suggests and as he himself affirms has a "thirst for justice" and has a "weak desire to re-establish respect to the memory of a human being who paid in this world for failures which were not entirely her own" (Ibidem, seg. 56). It is Father Justino who is at the centre of the gravity of the whole narrative, since it was he who had had the privileged access to the confession of Ana. He tells us:

Por mais longe que se procure, por mais desencontrados que sejam os caminhos que se percorrem, sempre teremos como ponto culminante os acontecimentos desta época - eles são o alicerce do edifício, a viga-mestra, a mola em torno do qual tudo gira. Está vendo, está assistindo plenamente o levantamento das linhas essenciais deste romance (CARDOSO, 1959, p. 498). 
One notices the complier behind the text here and we can see the compiler articulating the intertextual play of the various pieces being place together like a mosaic to give us the basic facts of the epic of the fall of the house of the Meneses.

This is indeed, a hierarchy of knowledge which is based on the involvement of each of the characters in the happenings of the farmhouse, and therefore with the possibility of the reestablishment of the facts years later. The basic family unity is the original three brothers, Demétrio, Timóteo and Valdo and to them are added the two wives, Ana and Nina. André, the supposed child of Nina, who had been born in Rio and brought back to the house by Ana is also important. It was the arrival of Nina just after her wedding that begins the chronology of action of the novel, although it is not the first thing in the narration. The figure of gardener is also important because of his affair with Nina and his subsequent suicide, which led to the return of Nina to Rio. Fifteen years later, she returns, sick, to die in the farmhouse. The recovery of this nucleus of the happenings is masterly achieved by the organiser.

Valdo gives just one statement, which implies that he was still alive when the inquest begins. But besides this direct statement in the segment 37 , he is indirectly present in both segment 10 and segment 22 when he communicates his view of the facts to Nina in the former and the doubts about the wisdom of the return of Nina in the latter, both in the form of a letter.

Oddly Demétrio, the head of the clan, has no voice and Lúcio Cardoso, in a note left on the original manuscript reveals that Demétrio does not speak, does not have a voice, like the very house itself. Nina is present through her long letters to the Colonel in Rio de Janeiro and to her husband Valdo. Through these letters, her point of view on some issues is clearly established and they explain the circumstances and the motives for her first departure from the farmhouse. However, she is always the centre of the happenings, and she is judged in the eyes of the others, according to their love, their hate or their distance from the facts as each one shows in his or her report.

But it is the diary of André, of Betty, the housekeeper and the book of memories of Timóteo which register the greatest personal variation about all the happenings. The housekeeper is objective and gives information in a matter of fact way, but hostile to the arrival and the staying of Nina in what had been in her mind a quiet household. It is the diary of André which is chosen to start the narrative, already with Nina dead in the front room. The memories of Timóteo appear only in the end of the book in segments 52 and 54 but his appearance dressed as a woman is filtered through a number of witnesses throughout the whole novel. We have the moment 
portrayed by Betty in the forth segment, described by Nina in the sixth, by Valdo in the fifty third as well as his own view of the happening narrated in segments 52 and 54 .

It is only through the doctor's report in segment 42 that we are in fact given the facts of the illness, cancer, which caused the death of Nina. It is in fact her wake, seen through the eyes of André in his diary which open the story of the novel.

The final statement of Father Justino, a priest who in normal times would be the master of certainties, moral and theological, gives the vision which had permeated the whole complex narrative of the facts in the farmhouse of the Meneses.

Assim é a verdadeira lei de Deus: pode assumir o aspecto e a cor do instante em que é citada. Dubiedade, transigência? Não, é que a verdade tem de cingir todos os aspectos da contingência humana. Que nos adianta ela quando abraça um único aspecto das coisas, e designar apenas uma face, que muitas vezes esconde a verdadeira essência dos fatos? Repito, a lei de Deus é mutável e vária, exatamente porque tem a candidez, a austeridade a fluência do líquido: penetra e umedece, a torna viva e fecunda a terra que antes não produzia senão a folhagem seca da morte. (CARDOSO, 1959, p. 498).

This vision of the mutability of the truth of God and the comparison with liquid is so far from the traditional truths of the Catholic church, but it fits in well with the ambiguity and complexity and uncertainty of the whole story related in the Crônica da casa assassinada. André sums it up wonderfully with his image of the "great coloured spiral". That is indeed, the best way of describing the narrative of the novel.

It is this complexity that makes the novel a perfect example of the modernist narrative. We have the segmentation of the angles of the telling, the justapositioning of the sequences, the temporal displacements and the setting linked to struggle of the language of the narrative to show human beings searching for stability and finding only change, in a fragmentation of points of view, the impossibility of reaching the final truth, the obsession with the final lose translated in the images of sin, of death, of illness. This is a masterpiece of a modernist, certain only that the truth is hard to show and the best that can be done is a presentation of a picture that does justice to it in its complexity, its ambiguity and its myriad points of view. The novel shows us the true nature of modernism, the epistemological doubt about the ability of the human being to reach objective and permanent truth. Our evaluation of the greatness of Lúcio and any other writer in this period must be a critical evaluation of his capacity to offer in his art, a text which is the ambiguous, the ironic and multiple in its point of view. 
It is now time to come to the basic task that examines whether Lúcio Cardoso should be included among the Brazilian postmodernists as some critics consider that he should. It is necessary to start from a definition of the nature of postmodernity and that is not an easy matter. There has been so much written on the subject and the conclusions are just about as varied as the writers on the subject. But it would seem interesting to start off with a clear position which is more or less that offered by critic McHale working in Israel who presents a view of the difference between the nature of modernism and postmodernism that allows an accommodation of the others definitions and understanding of postmodernism. According to him, while Modernism expresses an epistemological doubt about the capacity of the author or the artist and therefore the narrator to know reality, Post modernism goes further in the doubting and questions the very existence of this reality. There is a new and more radical doubt, the most profound of all doubts, the ontological doubt. There is, in this view, no reality or, at least, if there is, then it is not knowable. The best we can hope for is to pick up a few fragments of truth on this reality, and even if there is a contrary one to the other, there is truth in these fragments and are each one as valuable as any other. The partial truth of the subduing colonizer is only as true as that of the oppressed colonised. The moral certainty of the just is no better than the immoral perceptions of the wicked, and in fact all concepts of right and wrong are wrong from the start since there is no chance of us knowing what is objectively good or bad. All is fragmented and in this fragmentation, the objective truth, the objective reality, the lasting values disappear.

Other writers have put the same idea with a little more humour. Clarence Major in his novel Reflex and bone structure says "this book is an extension of, not a duplication of reality. The characters and events are happening for the first time" (MAJOR, 1975, preface). Raymond Federman in his novel Take it or leave it has the same type of disclaimer on the first page of his novel: "All the characters and places in this book are real, they are made of words, therefore any resemblance with anything written (published or unpublished) is purely coincidental" (FEDERMAN, 1976, preface). But both make their point. Fiction is not about representing reality, of copying reality in the former sense of mimesis.

Avoiding the temptation of classify Lúcio Cardoso as a postmodernist merely because his greatest novel was published after what most Brazilian critics consider the start of Brazilian postmodernism, it is now necessary to see whether we find in the text of Crônica da casa assassinada the foregrounding of the ontological doubt about reality. We have seen that the text foregrounded the epistemological doubt in the previous analysis, but it is now necessary to look more carefully 
at the text to see if it does not go a step further. We have seen that the book in its complex and brilliant narrative works towards an answer sifting through the reports of witnesses of different degrees of credibility in order to reconstruct and solve the unanswered question surrounding the life and guilt of Nina and the other characters of the farmhouse of the Meneses. But it would seem that it does not go any further that this. Lúcio Cardoso foregrounds the epistemological themes such as the accessibility and circulation of knowledge, the different structuring imposed on the same knowledge by different minds, the problem of unknowability and the limits of human knowledge.

But beyond this, Cardoso does not put in doubt the existence of this world in the interior of Minas which he had chosen as his enemy. There is nothing more solid than this Minas, with its banks, its flesh, its spirit. No doubts about its existence even if there is criticism of its values and during the whole complex narrative never does Lúcio Cardoso foreground the ontological question of the relationship of the real world and the fictional world. the basic task of every pre-postmodernist author of presenting reality is solidly accepted.

We must conclude then that the world of Lúcio Cardoso is growingly modernist and that his final novel Crônica da casa assassinada is definitely modernist with the complexity and the ambiguity which form the hallmark of all the great novels of this literary movement.

Therefore, we can conclude that Lúcio Cardoso is a fine example of a modernist in his literature, his connections with the theatre and cinema and does not move forward into a postmodernist mode at any stage of his literary production. He does not in the theatre reduce the haptic experience to performativity, nor his morals to vivential enrichment, and much more important, he does reduce his novels to discourse. His mastery verbal virtuosity presents us with a brilliant vision the real which brings us comprehension, ordering and as a result serenity in a complex, ambiguous and entertaining textuality.

\section{Resumo}

Este artigo reflete sobre as muitas opiniões acerca do autor da Crônica da casa assassinada como um escritor modernista ou pós-modernista. Examinando as técnicas narrativas utilizadas pelo autor, talvez influenciado por sua vasta leitura de literaturas estrangeiras relatadas, seria possível clarear um pouco esta questão do posicionamento de Lúcio Cardoso com relação aos movimentos literários do século XX. A experiência pessoal do escritor passa por um processo de impessoalidade, através da transmutação e amalgamação, transformando a obra em símbolo universal. Espera-se 
com esta comunicação discutir o modo como essa transmutação chega ao leitor em forma de um romance modernista e não, como às vezes se afirma, como um romance pós-modernista.

Palavras-chave: Lúcio Cardoso. Modernismo. Pós-modernismo.

\section{Referências}

CARDOSO, Lúcio. Crônica da casa assassinada. Rio de Janeiro, Civilização Brasileira, 1999

CARDOSO, Lúcio. Diário completo. Rio de Janeiro: José Olympio/INL, 1970. MAJOR, Clarence. Reflex and Bone Structure: A Novel. The Fiction Collective, New York, 1975

FEDERMAN, Raymond. Take It Or Leave It. The Fiction Collective, New York, 1997.

Submetido em: 14 de setembro de 2015 . Aceito para publicação em: 09 de outubro de 2015. 


\section{HOMENAGEM A YEDA PRATES BERNIS}


